\title{
Population genetics and demographic history of guava fruit fly Bactrocera correcta (Diptera: Tephritidae) in northeastern Thailand
}

\author{
Chonticha KUNPROM ${ }^{1}$, Piyamas NANORk SOPALADAWAN ${ }^{1,2}$ and Pairot PRAMUAL ${ }^{1,2, *}$

\begin{abstract}
${ }^{1}$ Department of Biology, Faculty of Science, Mahasarakham University, Kantharawichai District, Maha Sarakham 44150, Thailand;
\end{abstract} \\ e-mails: pairot.p@msu.ac.th; kwang.chonticha@outlook.co.th; piyamas.n@msu.ac.th \\ ${ }^{2}$ Biodiversity and Traditional Knowledge Research Unit, Mahasarakham University, Kantharawichai District, Maha Sarakham 44150 , \\ Thailand
}

Key words. Diptera, Tephritidae, Bactrocera correcta, DNA barcode, genetic variation, Pleistocene

\begin{abstract}
Bactrocera correcta (Bezzi) is among the most destructive fruit fly pests of the genus Bactrocera. This species infests 62 species of plants belonging 30 families, many of which are commercially important. In this study, the genetic structure, diversity and demographic history of $B$. correcta in Thailand were inferred from mitochondrial cytochrome $c$ oxidase I (COI) sequences. High genetic diversity was recorded in the 171 samples collected from 15 locations. This was due largely to the existence of two divergent lineages (I, II) revealed by median joining (MJ) network analysis. Genetic structure analysis revealed an overall low level of genetic differentiation between populations suggesting that the flies can move freely across geographic regions. Because the host plants are commonly grown in Thailand, continuity of habitats is the factor most likely responsible for the genetic homogeneity. In addition, the recent population history could also be a factor that contributed to the overall low level of the genetic structure. Mismatch distribution analysis as well as Tajima's $D$ and Fu's $F_{\mathrm{S}}$ tests detected evidence of recent demographic expansion dating back to the end of the last glaciations.
\end{abstract}

\section{INTRODUCTION}

The guava fruit fly, Bactrocera correcta (Bezzi) (Diptera: Tephritidae) was first recorded in Bihar, India in 1916 (Bezzi, 1916), and now occurs throughout South and Southeast Asia (Wang, 1996; Drew \& Raghu, 2002) and in China (Liang et al., 1996). B. correcta is one of the most destructive pests of the genus Bactrocera (Wang, 1996; Kitthawee, 2000). This species is highly adaptable, which has enabled it to rapidly spread geographically (Liu et al., 2013). B. correcta infests 62 species of plants belonging to 30 families (Allwood et al., 1999; Maynard et al., 2004) including several commercially important fruits such as mango, guava, peach, melon, cashew nut, cherry, jujube, carambola, wax apple, banana and citrus fruits (White \& Elson-Harris, 1992). Significant damage to commercial fruit crops is reported in Thailand and Vietnam (Drew \& Raghu, 2002). As B. correcta causes serious economic damage to fruit production and is highly invasive, it is considered to be a key quarantine species by many countries (White \& Elson-Harris, 1992; Maynard et al., 2004).

Information regarding genetic diversity, genetic structure and gene flow are crucial for pest control and management (Roderick, 1996; Roderick \& Navajas, 2003). For example, the sterile insect technique (SIT) uses sterile males to compete for mating opportunities with the wild males, but this method requires a large number of sterile flies, which should be in the same proportions as the number of wild flies (Itô et al., 2003). Information about effective population size and individual movement between populations (i.e. gene flow), which can be deduced from popula- tion genetic studies (Aketarawong et al., 2011; Karsten et al., 2013), is important for effective planning of releasing sterile insects. Despite it being an important pest species, which causes significant economic losses, the detailed genetic structure of this species is poorly studied.

The population genetic structure and demographic history inferred from molecular markers could also contribute to our understanding of the effect of past environmental changes (e.g. Pleistocene glaciations) on current biodiversity. Previous studies on insects, such as mosquitoes (O’Loughlin et al., 2008; Morgan et al., 2011), black flies (Pramual et al., 2005, 2011) and another species of fruit fly, Bactrocera latifrons (Hendel) (Meeyen et al., 2014), indicate the important role of historical climatic changes in determining the genetic structure and diversity of Southeast Asian faunas.

In this study, we use the mitochondrial cytochrome $c$ oxidase I (COI) gene to infer the genetic structure, diversity and demographic history of $B$. correcta in Thailand, especially in the northeastern part. Several studies have shown that COI sequences can be used for population genetic studies of fruit flies (Mun et al., 2003; Nardi et al., 2005; Shi et al., 2005, 2010, 2012; Hu et al., 2008; Prabhakar et al., 2012, 2013; Meeyen et al., 2014). We also investigated the genetic relationship between $B$. correcta in Thailand and samples from other geographic regions. The results of this study provide significant information on the genetic structure and diversity of this species of potential utility in pest management and control programs. In addition, the demographic history determined from this study will in-

\footnotetext{
* Corresponding author.
} 
TABLE 1. Details of the sites sampled and host-plant species of Bactrocera correcta in Thailand.

\begin{tabular}{|c|c|c|c|c|c|c|c|}
\hline Location & Code & $\begin{array}{l}\text { Geographic } \\
\text { region }\end{array}$ & $\begin{array}{l}\text { Latitude / } \\
\text { Longitude }\end{array}$ & $\begin{array}{l}\text { Altitude } \\
(\mathrm{m})\end{array}$ & Host-plant species & $\begin{array}{c}\text { No. of } \\
\text { samples }\end{array}$ & $\begin{array}{l}\text { Collection } \\
\text { date }\end{array}$ \\
\hline $\begin{array}{l}\text { Kantharawichai, } \\
\text { Maha Sarakham }\end{array}$ & MS1 & Northeast & $\begin{array}{c}16^{\circ} 14^{\prime} 58^{\prime \prime} \mathrm{N} \\
103^{\circ} 15^{\prime} 52^{\prime \prime} \mathrm{E}\end{array}$ & 166 & $\begin{array}{c}\text { Artabotrys siamensis Mig. } \\
\text { Syzygium samarangense } \\
\text { S. samarangense } \\
\text { S. samarangense } \\
\text { S. samarangense } \\
\text { Psidium guajava } \\
\text { P. guajava } \\
\text { Mangifera indica } \\
\text { Coccinia grandis } \\
\text { Sum } \\
\end{array}$ & $\begin{array}{c}1 \\
1 \\
2 \\
1 \\
3 \\
5 \\
2 \\
3 \\
1 \\
19 \\
\end{array}$ & $\begin{array}{l}08 / 05 / 2013 \\
22 / 04 / 2013 \\
23 / 04 / 2013 \\
23 / 04 / 2013 \\
25 / 04 / 2013 \\
28 / 07 / 2012 \\
01 / 03 / 2013 \\
20 / 07 / 2012 \\
29 / 05 / 2013\end{array}$ \\
\hline $\begin{array}{l}\text { Mueang, } \\
\text { Maha Sarakham }\end{array}$ & MS2 & Northeast & $\begin{array}{c}16^{\circ} 9^{\prime} 50^{\prime \prime} \mathrm{N} \\
103^{\circ} 19^{\prime} 45^{\prime \prime} \mathrm{E}\end{array}$ & 138 & $\begin{array}{c}\text { S. samarangense } \\
\text { S. samarangense } \\
\text { Malpighia emarginata } \\
\text { Muntingia calabura } \\
\text { P. guajava } \\
\text { Sum } \\
\end{array}$ & $\begin{array}{l}1 \\
2 \\
2 \\
1 \\
2 \\
8\end{array}$ & $\begin{array}{l}13 / 06 / 2013 \\
22 / 04 / 2013 \\
05 / 05 / 2013 \\
05 / 05 / 2013 \\
29 / 04 / 2013\end{array}$ \\
\hline $\begin{array}{l}\text { Na Dun, } \\
\text { Maha Sarakham }\end{array}$ & MS3 & Northeast & $\begin{array}{l}15^{\circ} 42^{\prime} 50^{\prime \prime} \mathrm{N} \\
103^{\circ} 13^{\prime} 37^{\prime \prime} \mathrm{E}\end{array}$ & 162 & $\begin{array}{c}\text { Irvingia malayana } \\
\text { Zizyphus mauritiana Lam. } \\
\text { Sum }\end{array}$ & $\begin{array}{l}2 \\
1 \\
3\end{array}$ & $\begin{array}{l}08 / 08 / 2012 \\
19 / 05 / 2013\end{array}$ \\
\hline Kham Muang, Kalasin & $\mathrm{KS}$ & Northeast & $\begin{array}{l}16^{\circ} 55^{\prime} 24^{\prime \prime} \mathrm{N} \\
103^{\circ} 37^{\prime} 54^{\prime \prime} \mathrm{E} \\
\end{array}$ & 201 & $\begin{array}{l}\text { Z. mauritiana Lam. } \\
\text { Sum } \\
\end{array}$ & $\begin{array}{l}4 \\
4 \\
\end{array}$ & $13 / 08 / 2012$ \\
\hline $\begin{array}{l}\text { Mueang, } \\
\text { Khon Kaen }\end{array}$ & KK1 & Northeast & $\begin{array}{l}16^{\circ} 32^{\prime} 41^{\prime \prime} \mathrm{N} \\
102^{\circ} 50^{\prime} 37^{\prime \prime} \mathrm{E}\end{array}$ & 173 & $\begin{array}{c}\text { P. guajava } \\
\text { Solanum melongena L. } \\
\text { Sum }\end{array}$ & $\begin{array}{c}8 \\
8 \\
16 \\
\end{array}$ & $\begin{array}{l}07 / 04 / 2013 \\
07 / 04 / 2013\end{array}$ \\
\hline $\begin{array}{l}\text { Si Chomphu, } \\
\text { Khon Kaen }\end{array}$ & KK2 & Northeast & $\begin{array}{l}16^{\circ} 49^{\prime} 30^{\prime \prime} \mathrm{N} \\
102^{\circ} 11^{\prime} 17^{\prime \prime} \mathrm{E}\end{array}$ & 226 & $\begin{array}{c}\text { M. marginata } \\
\text { Sum }\end{array}$ & $\begin{array}{l}11 \\
11\end{array}$ & $23 / 07 / 2013$ \\
\hline Khon San, Chaiyaphum & $\mathrm{CP}$ & Northeast & $\begin{array}{l}16^{\circ} 36^{\prime} 25^{\prime \prime} \mathrm{N} \\
101^{\circ} 54^{\prime} 35^{\prime \prime} \mathrm{E}\end{array}$ & 260 & $\begin{array}{l}\text { S. samarangense } \\
\text { Sum }\end{array}$ & $\begin{array}{l}10 \\
10\end{array}$ & $19 / 01 / 2013$ \\
\hline $\begin{array}{l}\text { Kut Chap, } \\
\text { Udon Thani }\end{array}$ & UD & Northeast & $\begin{array}{c}17^{\circ} 27^{\prime} 14^{\prime \prime} \mathrm{N} \\
102^{\circ} 25^{\prime} 35^{\prime \prime} \mathrm{E}\end{array}$ & 233 & $\begin{array}{l}\text { S. samarangense } \\
\text { P. guajava } \\
\text { Sum } \\
\end{array}$ & $\begin{array}{c}9 \\
9 \\
18 \\
\end{array}$ & $\begin{array}{l}20 / 05 / 2013 \\
20 / 05 / 2013\end{array}$ \\
\hline $\begin{array}{l}\text { Prang Ku, } \\
\text { Si Sa Ket }\end{array}$ & SK & Northeast & $\begin{array}{l}14^{\circ} 48^{\prime} 59^{\prime \prime} \mathrm{N} \\
104^{\circ} 04^{\prime} 00^{\prime \prime} \mathrm{E}\end{array}$ & 139 & $\begin{array}{l}\text { Averrhoa carambola } \\
\text { Z. mauritiana Lam. } \\
\text { Sum }\end{array}$ & $\begin{array}{c}7 \\
9 \\
16\end{array}$ & $\begin{array}{l}11 / 08 / 2012 \\
11 / 08 / 2012\end{array}$ \\
\hline $\begin{array}{l}\text { Mueang, } \\
\text { Ubon Ratchatani }\end{array}$ & UR & Northeast & $\begin{array}{l}15^{\circ} 13^{\prime} 44^{\prime \prime} \mathrm{N} \\
104^{\circ} 51^{\prime} 15^{\prime \prime} \mathrm{E}\end{array}$ & 121 & $\begin{array}{c}\text { S. samarangense } \\
\text { P. guajava } \\
\text { Sum } \\
\end{array}$ & $\begin{array}{c}1 \\
10 \\
11 \\
\end{array}$ & $\begin{array}{l}04 / 08 / 2012 \\
04 / 08 / 2012\end{array}$ \\
\hline $\begin{array}{l}\text { Pak Chong, } \\
\text { Nakhon Ratchasima }\end{array}$ & NR & Northeast & $\begin{array}{c}14^{\circ} 39^{\prime} 9^{\prime \prime} \mathrm{N} \\
101^{\circ} 26^{\prime} 02^{\prime \prime} \mathrm{E}\end{array}$ & 457 & $\begin{array}{l}\text { S. samarangense } \\
\text { Sum }\end{array}$ & $\begin{array}{l}15 \\
15\end{array}$ & $17 / 04 / 2013$ \\
\hline $\begin{array}{l}\text { PhannaNikhom, } \\
\text { Sakon Nakhon }\end{array}$ & $\mathrm{SN}$ & Northeast & $\begin{array}{l}17^{\circ} 19^{\prime} 23^{\prime \prime} \mathrm{N} \\
103^{\circ} 52^{\prime} 04^{\prime \prime} \mathrm{E}\end{array}$ & 211 & $\begin{array}{l}\text { M. indica } \\
\text { Sum } \\
\end{array}$ & $\begin{array}{l}10 \\
10 \\
\end{array}$ & $12 / 06 / 2013$ \\
\hline $\begin{array}{l}\text { Mueang, } \\
\text { Nakhon Pathom }\end{array}$ & NP & Central & $\begin{array}{l}13^{\circ} 48^{\prime} 51^{\prime \prime} \mathrm{N} \\
100^{\circ} 02^{\prime} 24^{\prime \prime} \mathrm{E}\end{array}$ & 7 & $\begin{array}{l}\text { S. samarangense } \\
\text { S. samarangense } \\
\text { Sum }\end{array}$ & $\begin{array}{c}1 \\
12 \\
13 \\
\end{array}$ & $\begin{array}{l}07 / 07 / 2013 \\
07 / 08 / 2013\end{array}$ \\
\hline $\begin{array}{l}\text { Bueng Sam Phan, } \\
\text { Phetchabun }\end{array}$ & $\mathrm{PB}$ & North & $\begin{array}{l}15^{\circ} 40^{\prime} 50^{\prime \prime} \mathrm{N} \\
100^{\circ} 56^{\prime} 07^{\prime \prime} \mathrm{E}\end{array}$ & 205 & $\begin{array}{l}\text { P. guajava } \\
\text { Sum }\end{array}$ & $\begin{array}{l}14 \\
14 \\
\end{array}$ & $04 / 06 / 2013$ \\
\hline Mueang, Chanthaburi & $\mathrm{CB}$ & East & $\begin{array}{l}12^{\circ} 37^{\prime} 03^{\prime \prime} \mathrm{N} \\
102^{\circ} 05^{\prime} 54^{\prime \prime} \mathrm{E}\end{array}$ & 10 & $\begin{array}{l}\text { S. samarangense } \\
\text { Sum }\end{array}$ & $\begin{array}{l}3 \\
3\end{array}$ & $24 / 05 / 2013$ \\
\hline Total & & & & & & 171 & \\
\hline
\end{tabular}

crease our fundamental understanding of the factors shaping biodiversity in Thailand. Finally, the COI sequences used in this study enlarge the DNA barcode database that is crucial for the success of DNA base species identification.

\section{MATERIAL AND METHODS}

\section{Sample collection and species identification}

Specimens were collected from natural habitats in Thailand, especially from the northeastern part, between March 2012 and
July 2013 (Table 1, Fig. 1). The infested fruits were placed in plastic boxes with a layer of sawdust in the bottom, covered by calico and kept at room temperature. After the adults emerged, flies were collected and stored in $80 \%$ ethanol at $-20^{\circ} \mathrm{C}$ until processing. Species were identified using adult morphological characteristics following White \& Elson-Harris (1992) and Plant Health Australia (2011). 


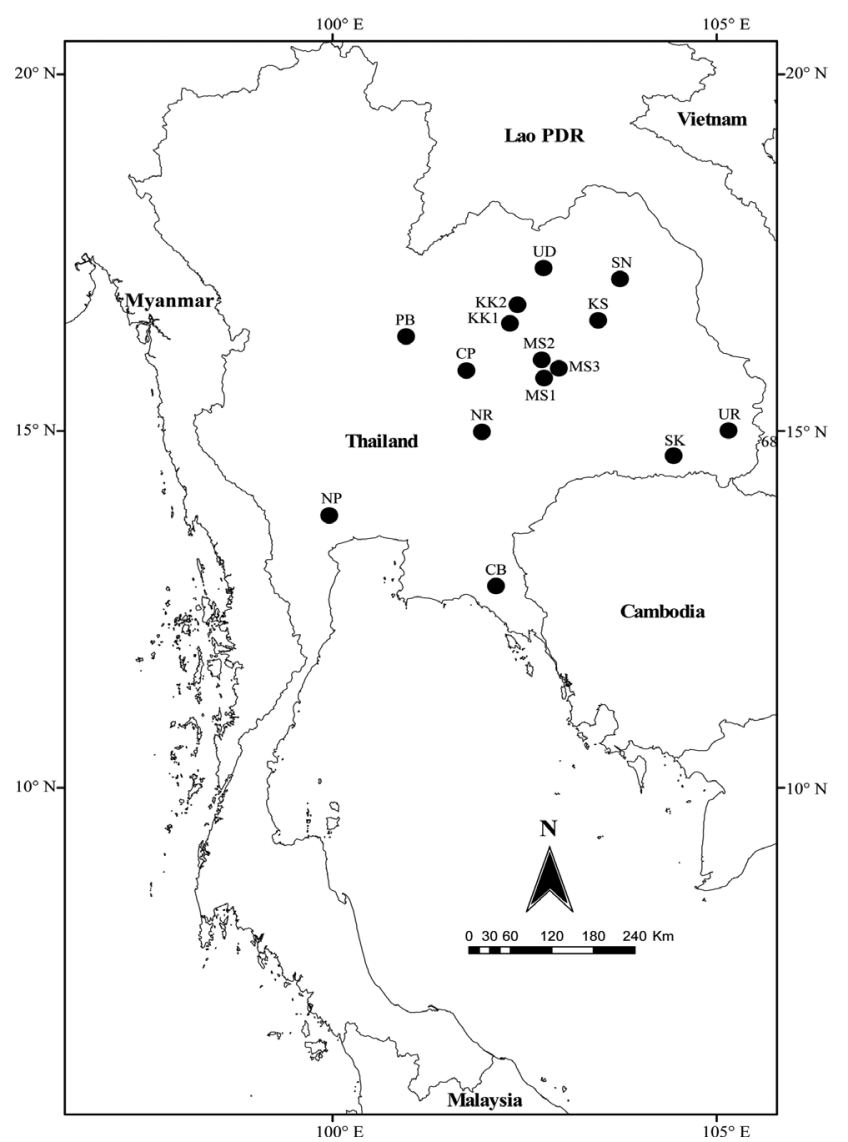

Fig. 1. Locations in Thailand of the 15 populations of Bactrocera correcta sampled. Details of the locations are given in Table 1.

\section{DNA extraction, amplification and sequencing}

Genomic DNA was extracted from individual adult flies using the GF-1 Tissue DNA Extraction Kit (Vivantis, Selangor Darul Ehsan, Malaysia). A 584-bp fragment of the mitochondrial cytochrome $c$ oxidase I (COI) gene was amplified using the primers LCO1490 (5'-GGTCAACAAATCATAAAGATATTGG-3') and HCO2198 (5'-TAAACTTCAGGGTGACCAAAAAATCA-3') (Folmer et al., 1994). Polymerase chain reaction (PCR) amplifications were carried out in a final volume of $50 \mu \mathrm{l}$ with conditions as described by Rivera \& Currie (2009). PCR products were checked using a $1 \%$ agarose gel and cleaned using the HiYield ${ }^{\mathrm{TM}}$ Gel/PCR DNA Fragments Extraction Kit (RBC Bioscience). Purified PCR products were sequenced using the same primers as in the PCR by Macrogen sequencing service (Seoul, Korea).

\section{Data analysis}

Haplotype diversity $(h)$ and nucleotide diversity $(\pi)$ were calculated using Arlequin v3.5.1.2 (Excoffier \& Lischer, 2010). The median joining (MJ) network (Bandelt et al., 1999) was used to estimate the genealogical relationships between haplotypes. The MJ network was calculated based on 209 COI sequences of $B$. correcta. Of these, 171 sequences were obtained in this study and 38 were obtained from GenBank (Accession nos. DQ116262 and JX 297530 from Viet Nam; JX297522-25, JX 297527-28, JX 456552 from China; JX 297529 from Laos; JX 297531 from Myanmar; KF289766, GU323781-82 from India; JQ692631, JQ692641，JQ692676，JQ692711，JQ692753，JQ692756, JQ692784, JQ692787, JQ692832, JQ692856 from Sri Lanka; and DQ116263-65, HM590450-51, JX 297532-38, AB568102,
TABLE 2. Haplotype diversity $(h)$ and nucleotide diversity $(\pi)$ of 15 populations of Bactrocera correcta in Thailand. Details of the locations sampled are given in Table 1.

\begin{tabular}{lccc}
\hline Location & $\begin{array}{c}\text { No. of } \\
\text { samples }\end{array}$ & $\begin{array}{c}\text { Haplotype diversity } \\
(h) \pm \mathrm{SD}\end{array}$ & $\begin{array}{c}\text { Nucleotide diversity } \\
(\pi) \pm \mathrm{SD}\end{array}$ \\
\hline MS1 & 19 & $0.9532 \pm 0.0358$ & $0.0079 \pm 0.0046$ \\
MS2 & 8 & $0.9643 \pm 0.0772$ & $0.0125 \pm 0.0075$ \\
MS3 & 3 & $1.0000 \pm 0.2722$ & $0.0174 \pm 0.0137$ \\
KS & 4 & $0.8333 \pm 0.2224$ & $0.0193 \pm 0.0134$ \\
KK1 & 16 & $0.7000 \pm 0.1274$ & $0.0093 \pm 0.0053$ \\
KK2 & 11 & $0.9636 \pm 0.0510$ & $0.0186 \pm 0.0105$ \\
CP & 10 & $0.9722 \pm 0.0640$ & $0.0325 \pm 0.0181$ \\
UD & 18 & $0.9739 \pm 0.0293$ & $0.0216 \pm 0.0115$ \\
SK & 16 & $0.9191 \pm 0.0438$ & $0.0094 \pm 0.0054$ \\
UR & 11 & $0.3455 \pm 0.1722$ & $0.0118 \pm 0.0068$ \\
NR & 15 & $0.8000 \pm 0.0771$ & $0.0076 \pm 0.0044$ \\
SN & 10 & $0.7778 \pm 0.0907$ & $0.0160 \pm 0.0091$ \\
NP & 13 & $0.9615 \pm 0.0412$ & $0.0149 \pm 0.0083$ \\
PB & 14 & $0.9890 \pm 0.0314$ & $0.0118 \pm 0.0066$ \\
CB & 3 & $1.0000 \pm 0.2722$ & $0.0115 \pm 0.0093$ \\
\hline Total & 171 & $0.9337 \pm 0.0118$ & $0.0132 \pm 0.0069$ \\
\hline
\end{tabular}

AB720881 from Thailand). MJ network analysis was performed in NETWORK v 4.6.1.2 (www.fluxus-engineering.com).

The population genetic structure was estimated using population pair wise $F_{\mathrm{ST}}$. The significance test statistic was obtained based on 1023 permutations. Sequential Bonferroni correction (Rice, 1989) was applied for the multiple tests. Analysis of molecular variance (AMOVA) was used to test the genetic differentiation among groups of populations from different host-plants and geographic regions as described in Table 1. Both population pair wise $F_{\mathrm{ST}}$ and AMOVA analyses were performed in Arlequin using the Kimura 2-parameter model (K2P). A Mantel test (Mantel, 1967) was used to determine the relationship between genetic distance $\left(F_{\mathrm{ST}}\right.$ from Arlequin) and geographic distance $(\mathrm{km})$ to test an isolation-by-distance (IBD) model. The Mantel test was implemented in IBD v1.52 (Bohonak, 2002) using 1000 randomizations.

Mismatch distribution was used to test the demographic history of the populations. A population that in the recent past has undergone a demographic expansion shows a unimodal mismatch distribution (Roger \& Harpending, 1992). The sum-of-squares deviation and Harpending's raggedness index (Harpending, 1994) were used to test the deviation from the prediction of the sudden expansion model. Mismatch distribution was estimated using Arlequin. Population expansion time was calculated using $\tau=2 \mathrm{ut}$ (where $\mathrm{u}=\mathrm{m}_{\mathrm{T}} \mu, \mathrm{m}_{\mathrm{T}}$ is the length of the nucleotide sequences under study, $\mu$ is the mutation rate per nucleotide and $t$ is the generation time (Roger \& Harpending, 1992)), assuming a divergence rate of $2.3 \%$ per million years for insect mtDNA (Brower, 1994) and eight generations per year based on the rearing information for $B$. correcta (Liu \& Ye, 2009). In addition, Fu's $F_{\mathrm{S}}$ test (Fu, 1997) and Tajima's $D$ (Tajima, 1989) statistical tests were also used to test for population equilibrium. The expectation is that these tests will yield large negative values during demographic population expansion.

\section{RESULTS}

\section{Mitochondrial DNA sequence variation}

A $584 \mathrm{bp}$ fragment of the mitochondrial COI gene was sequenced from 171 specimens of B. correcta from 15 locations in Thailand. Sequences were deposited in GenBank with the accession numbers KJ879751-KJ879921. A 


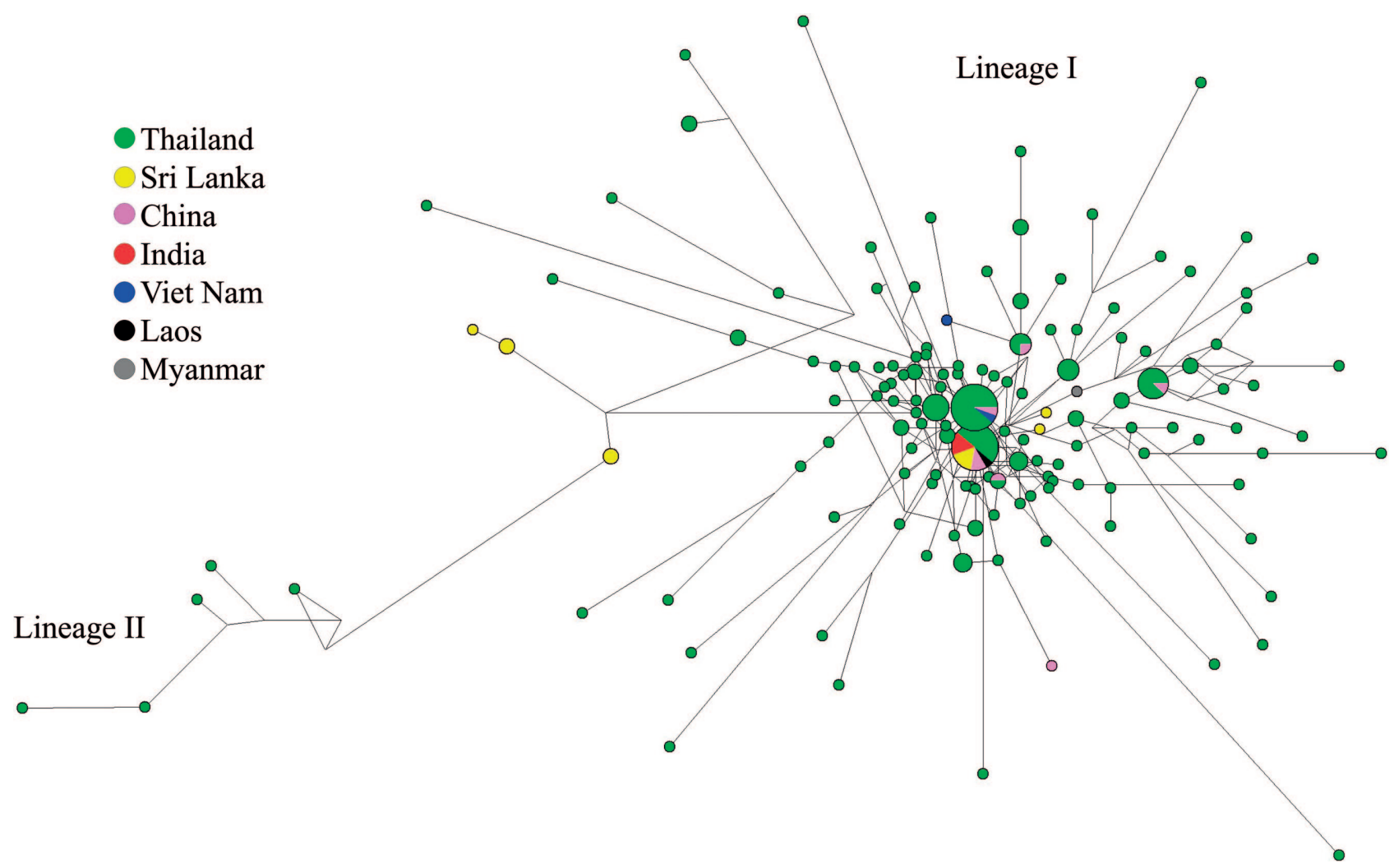

Fig. 2. Median Joining network of 209 COI sequences (171 sequences for Thailand and 38 sequences for other geographic regions) of Bactrocera correcta. Each circle represents a haplotype and sizes are relative to the number of individuals with a specific haplotype. Haplotypes are labelled according to country of origin.

total of 83 haplotypes were identified. The most common haplotype was recorded at all the locations sampled except Phetchabun (PB) and Chanthaburi (CB). This haplotype of Bactrocera correcta also occurs in India, Sri Lanka, Laos, Viet Nam and China. Haplotype diversity in each population ranged between 0.3455 in Ubon Ratchatani (UR) and 1.000 in Maha Sarakham (MS3) and Chanthaburi (CB) with an average of 0.9337 (Table 2). Nucleotide diversity in each population ranged between 0.0076 in Nakhon Ratchasima (NR) and 0.0325 in Chaiyaphum (CP) with an average of 0.0132 (Table 2).

\section{Mitochondrial genealogy}

The MJ network (Fig. 2) was calculated from 209 COI sequences (171 sequences obtained in this study and 38 sequences obtained from GenBank) of B. correcta. The MJ network revealed two distinct genetic lineages (I, II) among the members of $B$. correcta. Most specimens (204 sequences) belong to lineage I. Five specimens from Thailand [two from Maha Sarakham (MS1), two from Kalasin (KS) and one from Si Sa Ket (SK)] forming lineage II were connected to lineage I by 36 mutation steps. The haplotype

TABLE 3. Population pairwise $F_{S T}$ values between 15 populations of Bactrocera correcta in Thailand. Details of the locations sampled are given in Table 1. Bold characters indicate statistical significance at $P<0.05$.

\begin{tabular}{|c|c|c|c|c|c|c|c|c|c|c|c|c|c|c|c|}
\hline Population & MS1 & MS2 & MS3 & $\mathrm{KS}$ & KK1 & KK2 & $\mathrm{CP}$ & UD & SK & UR & NR & SN & NP & PB & $\mathrm{CB}$ \\
\hline$\overline{\mathrm{MS} 1}$ & 0.000 & & & & & & & & & & & & & & \\
\hline MS2 & 0.035 & 0.000 & & & & & & & & & & & & & \\
\hline MS3 & 0.202 & 0.120 & 0.000 & & & & & & & & & & & & \\
\hline KS & 0.152 & 0.119 & 0.120 & 0.000 & & & & & & & & & & & \\
\hline KK1 & 0.068 & 0.106 & 0.294 & 0.355 & 0.000 & & & & & & & & & & \\
\hline KK2 & 0.103 & -0.013 & 0.144 & 0.150 & 0.085 & 0.000 & & & & & & & & & \\
\hline $\mathrm{CP}$ & 0.145 & 0.014 & -0.011 & 0.015 & 0.164 & 0.022 & 0.000 & & & & & & & & \\
\hline UD & 0.075 & 0.003 & 0.120 & 0.124 & 0.032 & -0.009 & 0.062 & 0.000 & & & & & & & \\
\hline SK & 0.020 & -0.034 & 0.155 & 0.169 & 0.056 & 0.047 & 0.072 & 0.037 & 0.000 & & & & & & \\
\hline UR & 0.114 & 0.034 & 0.213 & 0.333 & 0.095 & 0.062 & 0.129 & 0.053 & 0.078 & 0.000 & & & & & \\
\hline NR & 0.105 & 0.041 & 0.366 & 0.409 & 0.038 & 0.054 & 0.118 & 0.022 & -0.001 & 0.071 & 0.000 & & & & \\
\hline SN & 0.211 & 0.042 & 0.353 & 0.175 & 0.254 & 0.018 & 0.037 & 0.029 & 0.121 & 0.197 & 0.214 & 0.000 & & & \\
\hline NP & 0.119 & -0.017 & 0.224 & 0.130 & 0.154 & 0.006 & 0.030 & 0.017 & 0.028 & 0.145 & 0.081 & -0.032 & 0.000 & & \\
\hline PB & 0.087 & 0.120 & 0.042 & 0.187 & 0.172 & 0.197 & 0.169 & 0.162 & 0.102 & 0.206 & 0.244 & 0.318 & 0.221 & 0.000 & \\
\hline $\mathrm{CB}$ & 0.075 & 0.058 & 0.145 & 0.202 & 0.030 & -0.010 & 0.003 & -0.037 & 0.046 & 0.034 & 0.119 & 0.247 & 0.121 & 0.168 & 0.000 \\
\hline
\end{tabular}




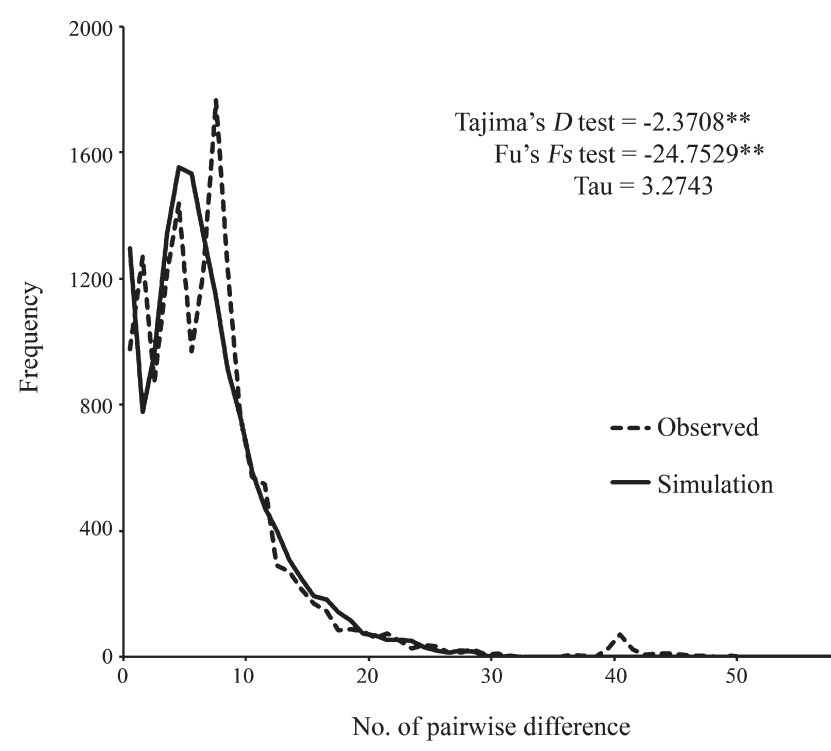

Fig. 3. Mismatch distribution of the $171 \mathrm{COI}$ sequences of Bactrocera correcta for Thailand in terms of the recorded and expected pairwise differences based on the predictions of the sudden population expansion model. Mismatch distribution for $B$. correcta is consistent with the predictions of the sudden population expansion model $(\mathrm{SSD}=0.0049, \mathrm{P}=0.8300$; Harpending's raggedness index $=0.0075, \mathrm{P}=0.9200)$.

cluster in the MJ network was associated neither with hostplants nor geographic origins (Fig. 2). Overall, the network has a star-like shape with a central haplotype shared by the globally distributed populations (Thailand, India, Sri Lanka, Laos, Viet Nam and China), which is characteristic of a recent demographic population expansion (Slatkin \& Hudson, 1991).

Genetic relationships between Thai $B$. correcta and sequences from other geographic regions are as follows. Three mitochondrial COI sequences from India have the same central haplotype. Two sequences from Viet Nam were made up of two haplotypes, of which one was unique and linked by a short branch length to haplotype group I, and one sequence has the central haplotype. One sequence from Laos had the central haplotype. Seven sequences from China included six haplotypes with one haplotype unique and connected to the central haplotype, three sequences had the central haplotype and three sequences had the same haplotypes as the Thai specimens and clustered in haplotype group I. Ten sequences from Sri Lanka were included in the MJ network analysis. Three sequences had the central haplotype and seven sequences included five unique haplotypes that linked them with haplotype group I. One sequence from Myanmar represented a unique haplotype and was directly connected to the central haplotype.

\section{Population genetic structure}

Population pairwise $F_{\mathrm{ST}}$ values revealed that most populations were not genetically significantly different (Table 3).The exception was the difference between Phetchabun (PB) and the other populations, where almost all $F_{\mathrm{ST}}$ values were statistically significantly different. AMOVA analyses by grouping populations according to their host-plant species and geographic regions found no significant genetic differentiation among the groups (Table 4). Mantel's test revealed no significant relationships $\left(r^{2}=0.0074, \mathrm{P}=\right.$ 0.3030 ) between genetic (pairwise $F_{\mathrm{ST}}$ ) and geographic distances.

\section{Demographic history}

Mismatch distribution analysis revealed a unimodal mismatch graph (Fig. 3), a characteristic of a recent population expansion. This is consistent with the star-like shape of the mtDNA genealogy. Both sum-of-squares deviation ( $\mathrm{SSD}=0.0049, \mathrm{P}=0.8300)$ and Harpending's raggedness index $(0.0075, \mathrm{P}=0.9200)$ were not significantly different from the simulated data predicted by the sudden population expansion model (Fig. 3). Population expansion was also supported by highly significant negative values of both Tajima's $D(-2.3708, \mathrm{P}<0.001)$ and Fu's $F_{S}(-24.7529$, $\mathrm{P}<0.001)$ tests. Time for which the population has been expanding is estimated to be approximately 15,000 years.

\section{DISCUSSION}

The genetic variation of $B$. correcta in Thailand, especially in the northeastern part of the country (ranges between $0.760 \%$ and $3.250 \%$ with an average of $1.312 \%$ ) based on the COI sequence, which is higher than that recorded for other species of fruit fly, including Bactrocera cucurbitae (Coquillett) (0.1\%-0.3\%) (Hu et al., 2008), Bactrocera oleae (Rossi) (0.09\%-0.48\%) (Dogac et al., 2013) and B. latifrons (0.09-0.86\%) (Meeyen et al., 2014). The level of genetic variation in $B$. correcta is also higher than that recorded for other species of fruit fly such as Bactrocera dorsalis (Hendel) (0.7\%-2.0\%) (Shi et al., 2012) and Bactrocera tryoni (Froggatt) $(0.5 \%-1.8 \%)$ (Blacket et al., 2012). The high level of genetic variation in B. correcta

TABLE 4. Results of the AMOVA analyses of 15 populations of Bactrocera correcta from Thailand, with grouping according to geographic regions and host-plants. $* P<0.05$.

\begin{tabular}{|c|c|c|c|c|}
\hline Source of variation & d.f. & SSD & Percentage of variation & $F$-statistic \\
\hline \multicolumn{5}{|l|}{ Geographic regions } \\
\hline Among groups & 4 & 30.0950 & 0.95 & $F_{\mathrm{CT}}=0.0095$ \\
\hline Among populations within groups & 10 & 67.1930 & 8.94 & $F_{\mathrm{ST}}=0.0989^{*}$ \\
\hline Within populations & 156 & 493.7880 & 90.11 & $F_{\mathrm{SC}}=0.0903 *$ \\
\hline \multicolumn{5}{|l|}{ Host plants } \\
\hline Among groups & 7 & 51.6120 & 1.96 & $F_{\mathrm{CT}}=0.0196$ \\
\hline Among populations within groups & 14 & 83.2570 & 11.00 & $F_{\mathrm{ST}}=0.1297 *$ \\
\hline Within populations & 144 & 445.1580 & 87.03 & $F_{\mathrm{SC}}=0.1123^{*}$ \\
\hline
\end{tabular}


is due largely to the existence of the divergent lineages revealed by the haplotype network analysis. These lineages are not associated with particular host plants or geographic regions. Although all individuals of lineage II were from northeastern Thailand, many other specimens from this region were clustered in lineage I. We have checked the species identification using COI barcoding sequences in the BOLD systems and found that all members of lineage II were a $100 \%$ match with $B$. correcta in the database. Thus, the possibility that the divergent lineage is a consequence of misidentification is unlikely.

Genetic divergence between the two lineages based on the $\mathrm{K} 2 \mathrm{P}$ model is $2.08 \%$, which falls in the range of the $3 \%$ cut-off value for DNA barcode sequences (Hebert et al., 2003). However, some studies have suggested that this cut-off value is not appropriate due to large variations in intraspecific genetic divergence (Meier et al., 2006). The values of interspecific genetic divergence estimated for 60 species of fruit flies range between $0.1 \%$ and $5.3 \%$ with a mean of $0.9 \%$ (Armstrong \& Ball, 2005). Therefore, it is not possible to determine here if the two lineages of $B$. correcta recorded in this study represent different species or not. However, because the two lineages are genetically distinct with low genetic divergence within each lineage, the results indicate no genetic exchange (i.e. gene flow) between the two lineages.

A previous study has also recognized two divergent lineages of B. correcta in Thailand. Jamnongluk et al. (2003) recorded that genetic distance based on COI sequences between two specimens of $B$. correcta collected from the same host plant (Syzygium samarangense) as considerable and claims that these two specimens represent two sibling species of $B$. correcta. The genetic divergence of these specimens was due to a Wolbachia infection, as one specimen was found to be infected with Wolbachia and the other not (Jamnongluk et al., 2003). Unfortunately, we were unable to include these specimens in our analysis because the COI fragment used by Jamnongluk et al. (2003) did not overlap our sequence. We were also not able to test for Wolbachia infection, thus this would be an interesting topic for further investigation.

Population pairwise $F_{\mathrm{ST}}$ values indicate an overall low level of genetic structuring between populations of $B$. correcta. The results are consistent with many other population genetic studies on fruit flies, which also detected low genetic structuring (Hu et al., 2008; Meeyen et al., 2014). Two factors most likely account for the genetic homogeneity among populations of $B$. correcta in Thailand. First, $B$. correcta utilizes a wide host range with 62 plant species belonging to 30 families (Clarke et al., 2001). Many host plants (e.g. mango, rose apple and guava) are commonly grown in Thailand and fruit fly populations are likely to be geographically continuous. In addition, human mediated dispersal such as local fruit transportation and trade could also facilitate movement of flies as has been reported in other fruit fly species (Malacrida et al., 2007; Shi et al., 2012). This could promote genetic exchange (i.e. gene flow) between populations that counters the effect of ge- netic drift or selection by lowering the level of genetic differentiation.

The second factor that could contribute to the low level of genetic structuring in B. correcta is its recent population history. Mismatch distribution analysis as well as the Fu's $F_{\mathrm{s}}$ and Tajima's $D$ tests indicate a recent demographic expansion in this species. The beginning of this expansion was estimated to be at the end of the Pleistocene glaciations (approximately 15,000 years ago). The results are consistent with previous studies on another fruit fly species, $B$. latifrons (Meeyen et al., 2014), and other insects such as mosquitoes (O'Loughlin et al., 2008; Morgan et al., 2011) and black flies (Pramual et al., 2005, 2011). Climatic conditions during the Pleistocene glaciations in tropical Asia, including Thailand, were thought to be drier with lower temperatures (Penny, 2001). These conditions lead to the contraction of tropical forests and the expansion of seasonally dry broad leaved dipterocarp forests (Penny, 2001). Climatic conditions returned to warm and humid about 18,000 years ago and this allowed the tropical forests to expand. Thus, the demographic expansion in B. correcta is most likely associated with an host-plant species expansion. The population expansion detected in $B$. correcta after the return to warm and humid climatic conditions is consistent with the present-day seasonal abundance of this species. Clarke et al. (2001) found that B. correcta reaches its peak abundance between May and September, which is the middle of the rainy season and coincident with host plant fruiting time.

The exception to the overall genetic homogeneity is the significant differentiation of the Phetchabun (PB) population. Most comparisons revealed significant $F_{\mathrm{ST}}$ values, which indicate limited gene flow between $\mathrm{PB}$ and the other populations. Geographically, this population is isolated from the others by a large mountain range (Phetchabun range). An ecological study of $B$. correcta indicated that mountain ranges are effective geographic barriers to dispersal because this species occupies low altitude areas (Liu et al., 2013). Mountain ranges are also important geographic barriers to gene flow in other fruit flies (Shi et al., 2005; Meeyen et al., 2014).

In conclusion, we found relatively high genetic diversity in $B$. correcta due to the existence of divergent lineages. Despite high genetic diversity, the overall genetic structuring was low except for one population that was isolated by a large mountain range, which acted as a barrier to gene flow. Demographic history analysis revealed the recent population expansion began at the end of the Pleistocene. As this is also recorded for other co-geographically distributed species in Thailand, it highlights the importance of late Pleistocene historical events in determining the genetic structure and diversity of species on tropical mainland in Asia.

ACKNOWLEDGEMENTS. This work was financially supported by a grant from Mahasarakham University. We would like to thank J. Dodgson and A. Plant for valuable comments on an earlier version of the manuscript. 


\section{REFERENCES}

Aketarawong N., Chinvinimull S., Orankanok W., Guglielmino C.R., Franz G., Malacrida A.R. \& Thanaphum S. 2011: The utility of microsatellite DNA markers for the evaluation of area-wide integrated pest management using SIT for the fruit fly, Bactrocera dorsalis (Hendel), control programs in Thailand. - Genetica 139: 129-140.

Allwood A.J., Chinajariyawong A., Drew R.A.I., Hamacek E.L., Hancock D.L., Hengsawad J.C., Jirasurat M., Kong Krong C., Kritsaneepaiboon S., Leong C.T.S. \& Vijaysegaran S. 1999: Host plant records for fruit flies (Diptera: Tephritidae) in South East Asia. — Raffles B. Zool. 7: 1-92.

ARMSTRONG K.F. \& BALL S.L. 2005: DNA barcodes for biosecurity: invasive species identification. - Phil. Trans. R. Soc. Lond. (B) 360: 1813-1823.

Bandelt H.J., Forster P. \& Rohl A. 1999: Median-joining networks for inferring intraspecific phylogenies. - Mol. Biol. Evol. 16: 37-48

BezzI M. 1916: On the fruit-flies of the genus Dacus occurring in India, Burma, and Ceylon. - B. Entomol. Res. 7: 99-121.

Blacket M.J., Semeraro L. \& Malipatil M.B. 2012: Barcoding Queensland fruit flies (Bactrocera tryoni): impediments and improvements. - Mol. Ecol. Res. 12: 428-436.

BoHonAK A.J. 2002: IBD (Isolation by Distance): a programme for analysis of isolation by distance. - Heredity 93: 153-154.

BROWER A.V.Z. 1994: Rapid morphological radiation and convergence among races of the butterfly Heliconius erato, inferred from patterns of mitochondrial DNA evolution. - Proc. Natl. Acad. Sci. USA 91: 6491-6495.

Clarke A.R., Allwood A., Chinajariyawong A., Drew R.A.I., Hengsamad C., Jirasurat M., Krong C.K., Kritsaneepaiboon S. \& ViJaysegaran S. 2001: Seasonal abundance and host use patterns of seven Bactrocera Macquart species (Diptera: Tephritidae) in Thailand and Peninsular Malaysia. - Raffles $B$. Zool. 49: 207-220.

Dogac E., KANDEMIR İ. \& TASKIN V. 2013: The genetic polymorphisms and colonization process of olive fly populations in Turkey. —PLoS One 8: e56067.

DREw R.A.I. \& RAGHU S. 2002: The fruit fly fauna (Diptera: Tephritidae: Dacinae) of the rainforest habitat of the Western Chats, India. — Raffles B. Zool. 20: 327-352.

EXCOFFIER L. \& LISCHER H.E.L. 2010: Arlequin suite version 3.5: a new series of programs to perform population genetic analyses under Linux and Windows. — Mol. Ecol. Res. 10: 564-567.

Folmer O., Black M., Hoen W., Lutz R. \& VriJenhoek R. 1994: DNA primers for amplification of mitochondrial cytochrome $\mathrm{c}$ oxidase subunit I from diverse metazoan invertebrates. - Mol. Mar. Biol. Biotech. 3: 294-299.

FU Y.X. 1997: Statistical test of neutrality of mutations against population growth, hitch hiking and background selection. Genetics 147: 915-925.

HARPENDING H.C. 1994: Signature of ancient population growth in a low-resolution mitochondrial DNA mismatch distribution. Hum. Biol. 66: 591-600.

Hartmann T. 1990: On-line DNA Alignment Software. Available at: http://www.fluxus-engineering.com/about.htm (accessed September 2013).

Hebert P.D.N., Cywinska A., Ball S.L. \& Dewaard J.R. 2003: Biological identifications through DNA barcodes. - Proc. $R$. Soc. Lond. (B) 270: 313-321.

Hu J., Zhang J.L., Nardi F. \& Zhang R.J. 2008: Population genetic structure of the melon fly, Bactrocera cucurbitae (Diptera: Tephritidae), from China and Southeast Asia. - Genetica 134: 319-324.
Itô Y., Kakinohana H., Yamagishi M. \& Kohama T. 2003: Eradication of the melon fly, Bactrocera cucurbitae, from Okinawa, Japan, by means of the sterile insect technique, with special emphasis on the role of basic studies. - J. Asia Pac. Entomol. 6: $119-129$

JAMNONGLUK W., Baimai V. \& KitTAYAPONG P. 2003: Molecular evolution of tephritid fruit flies in the genus Bactrocera based on the cytochrome oxidase I gene. - Genetica 119: 19-25.

Karsten M., VanvuUren B.J., Barnaud A. \& Terblanche J.S. 2013: Population genetics of Ceratitis capitata in South Africa: implications for dispersal and pest management. - PLoS One 8: e54281.

Kitthawee S. 2000: Seasonal occurrence of Diachasmimorpha longicaudata (Ashmead) (Hymenoptera: Braconidae), a parasitoid of Bactrocera correcta (Bezzi) (Diptera: Tephritidae) in a guava orchard in central Thailand. - Sci. Asia 26: 87-92.

Liang G.Q., YANG G.H. \& Liang F. 1996: Insects of Bactrocera (Diptera: Tephritidae) in Asia-Pacific area. Guangdong Science and Technology Press, Guangzhou, 479 pp.

LiU X. \& YE H. 2009: Effect of temperature on development and survival of Bactrocera correcta (Diptera: Tephritidae). - Sci. Res. Essays 4: 467-472.

LIU X., JIN Y. \& YE H. 2013: Recent spread and climatic ecological niche of the invasive guava fruit fly, Bactrocera correcta, in mainland China. - J. Pest Sci. 86: 449-458.

Malacrida A.R., Gomulski L.M., Bonizzoni M., Bertin S., GaSPeri G. \& Guglielmino C.R. 2007: Globalization and fruitfly invasion and expansion: the medfly paradigm. - Genetica 131: 1-9.

Mantel N. 1967: The detection of disease clustering and a generalized regression approach. - Cancer Res. 27: 209-220.

Maynard G.V., Hamilton J.G. \& Grimshaw J.F. 2004: Quarantine phytosanitary, sanitary and incursion management: an Australian entomological perspective. - Aust. J. Entomol. 43: 318-328.

Meeyen K., Nanorksopaldawan P. \& Pramual P. 2014: Population structure, population history and DNA barcoding of fruit fly Bactrocera latifrons (Hendel) (Diptera: Tephritidae). - Entomol. Sci. 17: 219-230.

Meier R., Shiyang K., Vaidya G. \& NG P.K.L. 2006: DNA barcoding and taxonomy in Diptera: a tale of high intraspecific variability and low identification success. - Syst. Biol. 55: 715-728.

Morgan K., O’Loughuin S.M., Chen B., Linton Y.M., Thongwat D., Somboon P., Fong M.Y., Bultin R., Verity R., Prakash A., Htun P.T., Hlaing T., Nambanya S., Socheat D., Dinh T.H. \& Walton C. 2011: Comparative phylogeography reveals a shared impact of Pleistocene environmental change in shaping genetic diversity within nine Anopheles mosquito species across the Indo-Burma biodiversity hotspot. - Mol. Ecol. 20: 4533-4549.

Mun J., Bohonak A.J. \& Roderick G.K. 2003: Population structure of the pumpkin fruit fly Bactrocera depressa (Tephritidae) in Korea and Japan: Pliocene allopatry or recent invasion. Mol. Ecol. 12: 2941-2951.

Nardi F., Carapelli A., Dallai R., Roderick G.K. \& Frati F. 2005: Population structure and colonization history of the olive fly, Bactrocera oleae (Diptera: Tephritidae). - Mol. Ecol. 14: 2729-2738.

O’Loughlin S.M., Okabayashi T., Honda M., Kitazoe Y., Kishino H., Somboon P., Sochanta T., Nambanya S., Saikia P.K., Dev V. \& WaLton C. 2008: Complex population history of two Anopheles dirus mosquito species in south Asia suggests the influence of Pleistocene climate change rather than human-mediated effects. - Evol. Biol. 21: 1555-1569. 
PenNy D. 2001: A 40000 year palynological record from northeast Thailand, implications for biogeography and palaeo environmental reconstruction. - Palaeogeogr. Palaeocl. 171: 97-128.

Plant Health Aaustralia 2011: The Australian Handbook for the Identification of Fruit Flies. Version 1.0. Plant Health Australia, Canberra, ACT, 214 pp.

Prabhakar C.S., Mehta P.K., Sood P., Singh S.K., Sharma P. \& Sharma P.N. 2012: Population genetic structure of the melon fly, Bactrocera cucurbitae (Coquillett) (Diptera: Tephritidae) based on mitochondrial cytochrome oxidase (COI) gene sequences. - Genetica 140: 83-91.

Prabhakar C.S., Sood P., Metha P.K. \& Sharma P.N. 2013: Population genetic structure of the pumpkin fruit fly, Bactrocera tau (Walker) (Diptera: Tephritidae) in Himachal Pradesh, India. Biochem. Syst. Ecol. 51: 291-296.

Pramual P., Kuvangkadilok C., Baimai V. \& Walton C. 2005: Phylogeography of the black fly Simulium tani (Diptera: Simuliidae) from Thailand as inferred from mtDNA sequences. Mol. Ecol. 14: 3989-4001.

Pramual P., Kongim B. \& Nanork Sopaladawan P. 2011: Phylogeography of Simulium siamense Takaoka and Suzuki complex (Diptera: Simuliidae) in Thailand. - Entomol. Sci. 14: 428-436.

RICE W.R. 1989: Analyzing tables of statistical tests. - Evolution 43: 223-225.

RiverA J. \& CURRIE D.C. 2009: Identification of Nearctic black flies using DNA barcodes (Diptera: Simuliidae). - Mol. Ecol. 9: $224-236$.

Roderick G.K. 1996: Population genetics studies of Tephritid flies of economic importance. In McPheron B.A. \& Steck G.J. (eds): Fruit Fly Pests: A World Assessment of Their Biology and Management. St. Lucie Press, Delray Beach, FL, pp. 267271.
RoDerick G.K. \& NavaJas M. 2003: Genes in new environments: genetics and evolution in biological control. - Nature Rev. (Genet.) 4: 889-899.

Roger A.R. \& Harpending H. 1992: Population growth makes waves in the distribution of pairwise genetic differences. Mol. Biol. Evol. 9: 552-569.

Shi W., Kerdelhué C. \& Ye H. 2005: Population genetics of the oriental fruit fly, Bactrocera dorsalis (Diptera: Tephritidae), in Yunnan (China) based on mitochondrial DNA sequences. Environ. Entomol. 34: 977-983.

Shi W., KerdelhuÉ C. \& Ye H. 2010: Population genetic structure of the oriental fruit fly, Bactrocera dorsalis (Hendel) (Diptera: Tephritidae) from Yunnan province (China) and nearby sites across the border. - Genetica 138: 377-385.

Shi W., Kerdelhué C. \& Ye H. 2012: Genetic structure and inferences on potential source areas for Bactrocera dorsalis (Hendel) based on mitochondrial and microsatellite markers. - PLoS One 7: e37083.

Slatkin M. \& Hudson R.R. 1991: Pairwise comparisons of mitochondrial DNA sequences in stable and exponentially growing populations. - Genetics 129: 555-562.

TAлIMA F. 1989: Statistical methods for testing the neutral mutation hypothesis by DNA polymorphism. - Genetics 123: 585-595.

WANG X.J. 1996: The fruit flies (Diptera: Tephritidae) of the East Asian region. - Acta Zool. Sin. (Suppl.) 21: 1-338.

White I.M. \& Elson-Harris M.M. 1992: Fruit Flies of Economic Significance: Their Identification and Bionomics. CAB International, Wallingford, $601 \mathrm{pp}$.

Received August 3, 2014; revised and accepted December 10, 2014 Prepublished online February 3, 2015 